\title{
LUCAS, KEYNES, AND THE CRISIS - ERRATUM
}

\author{
BY \\ DAVID LAIDLER
}
doi: 10.1017/S1053837209990423, Published by Cambridge University Press, 01 February 2010.

It is regretted that the originally published paper (Laidler, 2010) did not contain the correct abstract, presented below. We apologize for the oversight.

This paper examines Robert E. Lucas's views on the relationship of macro-economics to real world economic phenomena, and on Keynes's place in its history, suggesting that these stem from a particular and debatable understanding of how the sub-discipline has evolved. It argues that Keynes's General Theory does indeed have implications for today's awkward economic facts, not so much its speculations about the role of psychology and social conventions in the economic decisions of individual agents recently highlighted by Akerlof and Shiller (2009) however, as its insights into the influence of the monetary system on the coordination of these decisions, along lines later extended by Clower (1965) and Leijonhufvud (1968). It concludes that the questions about co-ordination that Keynes, along with so many of his contemporaries, addressed, not to mention some of their answers, are well worth revisiting.

\section{REFERENCE}

Laidler, D. 2010. "Lucas, Keynes, and the Crisis." Journal of the History of Economic Thought 32 (March): 39-62. doi: 10.1017/S1053837209990423. 